\title{
A NEW EDUCATIONAL MODEL FOR CRIMINALITY PREVENTION
}

\author{
Emilian M. Dobrescu ${ }^{1}$, \\ Tiberiu-Viorel Popescu ${ }^{2}$
}

\begin{abstract}
Solon said that, in order to be free, a citizen had to study; education was the ground of democracy and in Athens there was no illiterate citizen. The education was both of the body as well as of the soul in a natural continuity... Plato was even aware that in all that there was, there was a core of "dissension" (entropie) that sooner or later led to the fall. He tried to set a fortress model that would minimize the effects of this core of destruction. In the dialogue entitled „Republica”, he pointed out that it was in the power of man to minimize the evil and to build a harmonious fortress that would prevent the destruction. The idea of harmony, which is to be found also in music and mathematics, is extended also to the relations between people... „Man can complete itself through education and culture. I feel sorry that people do not see these simple things and we witness a rush of goods and pleasures, a hedonism that has been before. The contemporary man does not realize that the Humanity has already gone through such situations and is in danger to repeat them, danger that could be avoided through knowledge and understanding”, says today, a few thousand years since the release of Plato's theory, our compatriot, Univ. Prof. Dr. Nicolae Săcăliş-Calata ${ }^{3}$.
\end{abstract}

Key words: model of education, new educational model, deficient social education, criminality prevention strategy.

JEL codes: A14, I23, K14

\section{Introduction}

The American model of education is no longer up to date.

„Consume, consume, consume! Have you got no money? We grant you a credit. Can you afford the credit? We have the solution: another credit by means of which you should pay the first credit! You only have to consume, we take care of the rest". And the rest is already History ${ }^{4}$, even the history of our time, including here, in Romania.

Mr. Samuel Whybrow, head of the Semel Institute for Neuroscience and Human Behavior at UCLA, stated, argued a theory that is both rightful as well as moving. In fact, man is incapable, from the biological point of view, to live the American dream... „We were taught”, says Whybrow, that ,happiness will be reached at the end of a material road, after a gathering of assets, that we were manipulated to long for". The title of his book - American Mania: When More Is Not Enough - says it all. The contemporary primary human tendencies, the result of million of years of evolution driven by poverty, no longer correspond to the modern world that we built. Within this context, out nervous system, based on dopamine reward, has become addicted to immediate gratification. This leads to the destruction of the natural balance between future and present.

\footnotetext{
${ }^{1}$ Academia Română, Bucureşti, dobrescu@acad.ro

${ }^{2}$ Academia Română, Bucureşti.

${ }^{3}$ Elena Solunca, Memoria culturală - sursă de învăţătură a realităţii, talkshow with Ph.D. Nicolae Săcăliş-Calata, in Curentul, August $14^{\text {th }} 2009$, p. 13.

${ }^{4}$ Cristian Crisbăşan, Ipoteca pe viitor, in Sunday Newspaper, November $7^{\text {th }} 2008$, p. 8.
} 
We stuff ourselves with ,junk-food" rich in cholesterol and alimentary additives using the credit cards in order to purchase goods that, in fact, we normally could not afford. And then, exhausted by work, sleepless and harassed, we come down with anxiety and depression. We reach to that anesthetic falling asleep of vigilance. Genuinely, the credit means to make yourself slave to a utopia, since, after you bought anything you had wanted - mortgaging your future - you discover that it isn't, in fact, happiness. The markets ... no longer limit our excesses, but, on the contrary, they encourage them. This may sound like: ,consume more and more so I could grant credits also to another person that would consume in its turn more and more. The instinctual brain is far ahead of the intellectual one"... Which is the solution? ... One of them has particularly drawn my attention: „People could teach their children to live modestly and to correctly identify their needs”.

The American consumption model or the European one of ,the status of general prosperity" lives its last moments (days, weeks, maybe even years...). The shorter these „moments” will be, the sooner mankind will bring to a direction that has never known in its evolution, a direction that could allow it the profound, but not formal coming back to the scale of existence and perennial becoming. And, for this purpose, it is necessary a new education from a very early age and up to the most advance one, a new way to perceive existence by each of us as some of us (very few, initiated in this new way of thinking and action) or others (the greater part that only think about the physical abundance that, unfortunately, they never manage to reach...) have never done it before.

\section{True cause of the repetition of the crises - deficient education}

Ironically, in supporting the above said, the matter of financial education has been in the agenda of the European Union and that of the member states even since summer of 2007, but it was not enough promoted and brought into discussion. So, the European policies were formulated in order to carry out some closer objectives, such as a better financial communication and informing of the consumers and their better protection. Instead, it has not done too many things for the carrying out of the long - term educative objectives, because the power of the EU in this field is in fact pretty limited. Although the subject has clear financial implications and a direct on the Common Market, the educative matter is still one of national competence.

The European Commission has mentioned the key role of education in a series of documents since early 2005, supporting the member states to adopt efficient improvement measures of the financial competences. On two occasions, in 2006 and 2007, the Ecofin Council of the EU underlined the ,importance of supporting the financial education and the level of informing of the consumers in the member states". The introduction of the new pension systems by various member states, that make the employees responsible in the autonomous investment of a part of their own pension funds, valued greatly the financial education. Many observers sustain that the lack of financial understanding among the American consumers has fed the present crisis. The informed consumers could have avoided the purchase of risky products suggested by the managers given to take certain risks. So, a weak informing system of the consumers and mostly the uncontrolled sale of the complex and risky products underlay the maximum of negative evolution of the financial crisis in September - October 2008.

The organizations of the consumers also underline the importance of the financial education. According to the European rules, the banks have to appropriately inform its customers when selling their financial products and to warn them about the taken risks. In its turn, the consumers must have the capacity to easily compare various banking products, the characteristics of which they know. In April 2008, the Council of Ministers approved a revised directive regarding the consumption credit through which it had in view the protection increase and harmonization of the European citizens that take a loan. The directive aims the standardization of the information that have to be released to the press in order to ease the comparison of various loan offers by the consumers. 
The true cause of the repetition of the crises is in fact the deficient individual and social education. So, it is necessary the change of the way that the citizens are educated during their lives. Albert Einstein, one of the greatest figures of mankind, said about the crisis the following: „The crisis can be a real blessing to any person, to any nation. For all crises bring progress. Who overcomes crisis, overcomes himself, without getting overcome. Incompetence is the true crisis. The greatest inconvenience of people and nations is the laziness with which they attempt to find the solutions to their problems. There's no challenge without a crisis. Without challenges, life becomes a routine, a slow agony. There's no merit without crisis. It's in the crisis where we can show the very best in us... To speak about a crisis is to promote it. Let us work hard instead.... Let us stop, once and for all, the menacing crisis that represents the tragedy of not being willing to overcome it».

In the beginning of the last decade of November 2009, European deputy Lothar Bisky (EUL/NGL, Germany) asked the Chairman of the European Commission if he was ready "because the new Commission has learned the lesson of the false market economy". Barroso underlined that the stress would be laid on education, continuous training, mobility of the workers and fight against social exclusion and poverty.

\section{Deficient social education - main cause of criminality}

So, besides the financial education, the deficient individual and social education represents a cause of the crisis aggravation and, as its result, the generation of antisocial behaviors.

Paul Samuelson said that money represented the blood that irrigated the economy. Starting from this consideration, we can state that, due to the great importance that money has within the economic mechanism, its procurement, through more or less illegal means, has always represented a great temptation for people. The irresistible temptation of getting larger and larger amounts of money has caused various forms of manifestation of the criminal behavior, the origin of which is either the lack of money, or the above- mentioned hedonism that often animates people, but which has always have as purpose the gaining of benefits that would generate financial welfare.

Such deviant behaviors from the natural conduit negatively affected the economy of various states as a result of generating an unstable, consequently infertile business environment with the obvious consequence of the slowing down of the economic progress.

The anomy, characterized both by a lack of observance of the legal norms as well as by a moral reclamation that leads towards nihilism, is based on the same ignorance, the source of which is the deficient education. So, the legal norm is no longer perceived as a regulation with general and mandatory character meant to contribute to the maintenance of the legal order as integrant part of the social order. The coercive character of the legal norm is made relative on conditions on which the coercion force of the state is applied on discretion based on criteria that suppress the fundamental rightful principle of equality before the law (C. Bulai, 2007, p. 25).

On such generated conditions, the criminality becomes a phenomenon of proportions with direct consequences both on the society as well as on the economy of the states that are in such situations. The consequences and cost of the criminality, violence and lack of safety are often impossible to quantify. The damages in the developed countries represent about $5 \%$ of the Gross Domestic Product and in the developing countries it can reach up to $14 \%$ of the Gross Domestic Product ${ }^{5}$.

Between education (received from family and school) and criminality, there is undoubtedly a direct connection which is centered on person. For the man aware of its lack of value, without no

\footnotetext{
${ }^{5}$ UN ECOSOC, Report of the Committee: Working meeting on the involvement of the community in the criminality prevention: $10^{\text {th }}$ Congress for the criminality prevention and the offenders' treatment, Vienna, April $10-17^{\text {th }} 2000$ : quoted by A. Bălan - Feminine Criminality, CH Beck Publishing House, Bucharest, 2008, pp. 216-217
} 
prospect of a future, the observance of the law in an environment does not antimate the anomy, is perceived as a useless luxury. Besides, the studies of criminology point out that the criminal is not only socially inadapted, but also reluctant to any form of re-socialization. For this reason, the prevention of the criminal behavior represents a priority.

\section{A criminality prevention strategy - education}

The present studies of criminology recommend a stress on the criminality prevention strategies, because in criminology, the interest in criminality prevention is a priority (Stănoiu R. M., 1994, p. 199-213). The modern criminological researches are mainly based on the identification of the ways and means of fighting against crime and criminality. In general, the doctrinaires join the opinion according to which the fight against crime has to be watched under two aspects, a preventive one of preventing the crimes committing (ante delictum) and a repressive one of punishing those that commit crimes (post delictum).

Through prevention, it should be understood the taking of measures that prevent or stop the crime committing. An important step in this sense is the education in the spirit of observing the fundamental social and moral values from the first years of school. This contributes a great deal to the shaping of the individual in full progress of formation of the personality balance.

This kind of prevention is similar, from the semantic perspective, to the prevention of a malady in the medical field. This prevention will be reflected in practice similar to applying some preventive medical measures due to which a disease either does not break out or does not extend. In the medical field, there is a general principle that can be applied also to crime prevention, that is, it is easier to prevent (a disease) than to heal. Besides, it is important to underline that in the case of criminality prevention, the prevention is a measure more than necessary, because, if the crime were committed, it would result important costs of this (victims, damages) often difficult to replace and sometimes irreparable after having been committed.

Under the auspices of these ideas, although the authors of the present criminological doctrine mention that the idea of prevention belongs to the ancient philosophers ${ }^{6}$, they dedicate a generous space to this matter ( M. Killias, 1991).

Taking into consideration the fact that the lack of concern for the individual and social education or the deficient education can easily change the scale of values to which the society report itself, leads to the ignoring of the fundamental social and moral values that assure the stability, progress and safety of the society. The ignorance of the badly educated individual that has reached the stage of losing its capacity of self-determination has no longer the discernment to separate what is right for itself from what it does for the benefit of others and its own detriment.

Within this context, it is very important to underline the importance of formation through education of a thinking model capable to protect the individual from the temptations that can occur on the background of a deficient representation of the social values. In fact, the education has to be aimed also towards the direction of instilling the correct perception over the law that will instill the virtues of this one. This can be the result of three aspects: the certainty of repairing the law infringement (man should know that he will be traced for any illegalities), punishment severity (the illegality leads to severe consequences) and the most important, the punishment certainty (there is no possibility to avoid enforcement). In this manner, the society is also protected against the present challenges that affect more and more the progress of the societies where the law is applied under these auspices.

\footnotetext{
${ }^{6}$ See Plato, Opere, vol. 1, Protagora 3, 24, Ştiinţifică Publishing House, Bucharest, 1974; Aristotel, Rhetorique et art poetique, traduit par J. Voilquin et J Capelle, cap. 12, Paris, Garnier, 1944, quoted by R. M. Stănoiu, în Tranziţia şi criminalitatea, Oscar Print Publishing House, Bucharest, 1994, pp. 200-201
} 


\section{Conclusions}

The responsible influencers and the individuals directly involved in the process of globalization deal, directly or indirectly, with the thinking and enforcement of some measures that influence the education and the effects of education over the individuals from different parts of the planet. In the globalization process, devastating for the planet and the human beings, we suggest that the most urgent measures that have to me taken in the field of education, at the level of each country, are the following ones ${ }^{7}$ :

1. Profound, thorough and prognostic implication of the professional societies, such as, the Society of Mathematics, the Society of Physics, the Society of Chemistry, the Society of Biology, here in Romania, in the training process.

2. Stress of the phenomenon of education on the practical training, the formation of competences through experiences in the laboratories (even demonstrative ones where there are no materials). A special concern for the minimum, standard endowment of the school laboratories.

3. School on various levels in order to grant access and equal chances to everybody, but to cultivate also the elites. Special programs for more gifted, gifted above the average pupils/ students and - mutually - for pupils/ students with deficiencies.

4. The teacher, textbook and computer have to support themselves and to value mutually in the modern education process. The computer and the Technologies of Informatics and Communication (TIC) have to be seen as a part of the education process and not as a formal substitute of the textbook or of the teacher.

5. The computer should be used as a teaching and learning instrument, not as a purpose in itself. The use of the computer should be dynamic and the teacher should check the hypotheses by means of the computer in the attempt to theoretically justify, but not to limit itself just to reading a text on the display, should present a documentary film and should make simple comments.

6. Setting of an experimental character in teaching the humanities, but especially the natural history. Understanding of education in the exact sciences and especially in mathematics the main means for the formation of the major competences of the modern man: the right thinking and the possibility of a logic argument of any type.

7. More profound use of the experimental character of the natural history for the formation of the capacity to switch from the particular to the general. The increase of the role of the experiments in order to form the analytical thinking of the subjects and not only to cultivate their practical competences.

8. Elaboration of some didactic programs with less details than they are at present that should base themselves more on the switch from the particular to the general, as well as on the appeal to intuition, experiment and critical character. Cancellation of focusing of the instructiveeducative process on the transmission of information or their memorization and automatic rendition in the examination/ evaluation process. Complete elimination, irrespective of the level of that particular school, of the tests with previously published subjects and solutions and the eventual going to tests with random (computerized) allocation that would cover the entire curriculum.

9. Gaining of some key- competences in natural history, social sciences and humanities, such as: practical competences; competences of studying during the entire lifetime; digital competences of handling the computer or laptop.

\footnotetext{
${ }^{7}$ apud $* * *$, Raport sinteză privind audierea publică din 28 oct. 2009 pe tema Formarea de competenţe: o necesitate pentru societatea secolului XXI? (selective), on site www.Sinteza_SAR_AA_Siveco_11091752.pdf, visited on December $17^{\text {th }} 2009$
} 
10. Focusing on the needs expressed by the business environment and the exigencies on the labor force market, on the studying and processing of the needs of the business environment in the curriculum drawing up.

11. Introduction of the innovative education, skip to the pedagogy based on investigation and discovery, observation, analysis and synthesis. Development of the rational capacities of the subject, understanding of the carrying on of the phenomena and not their memorization.

12. Development of the habits to act in a given situation based on the previously obtained information and abilities; the educational actor has to autonomously judge a real life problem, to form an opinion and find an answer.

\section{References}

1. Bălan A., 2008. Criminalitatea feminină, Bucureşti, Printing House C. H. Beck

2. C. Bulai, 2007. Textbook of criminal law, Universul Juridic Publishing House, Bucharest,

3. Boulois J., 1993. Droit institutionnel des Communautes Europennees, avec references au Traite sur l'Union Europeenne, Paris, Editons Quatrieme, Montchrestien

4. Filipescu Ion P. şi Fuerea A. 1996. Drept instituţional comunitar european, 2nd Edition , Bucureşti, Printing House Actami

5. Isaac G., 1990. Droit communautaire general, Troisieme Ed., Paris, Masson

6. Killias M., 1991. Précis de criminologie, Berne, Ed. Staempfli \& Cie SA

7. Munteanu R. 1996. Drept european - evoluţie, instituţii, ordine juridică, Bucureşti, Oscar Print

8. Pinto R., 1963. Les organisations europeennes, Paris, Payot

9. Stănoiu R. M., 1994. O nouă perspectivă în prevenirea criminalităţii, in vol. Tranziţia şi criminalitatea, Bucureşti, Printing House Oscar Print 